\title{
DESIGNING MULTILINGUAL AND MULTICULTURAL CURRICULUM
}

\author{
A.M. Gilmetdinova ${ }^{1}$ \\ Kazan National Research Technical University named after A.N. Tupolev-KAI \\ 10, K. Marks st., Kazan, 420111, Russian Federation \\ E-mail:Alsu.Gilmetdinova@kai.ru
}

\begin{abstract}
What is the relationship between language and culture? What role do language and culture play in designing curriculum that is inclusive of the needs of linguistically and culturally diverse students? What does multicultural and multilingual curriculum development look like? Scholarship on multicultural education acknowledges a strong interactive relationship between language, culture and learning and includes the benefits of bilingual instruction for multilingual students [10]; yet, often the assumption is that "coming to voice takes place in English only" [22]. Similarly, curriculum development for multicultural education is mainly done in the English language. The purpose of this article is to integrate both culture and language into the review of curriculum development that embraces both linguistic and cultural needs of diverse students. Using Sleeter's [37] Un-Standardizing curriculum: Multicultural teaching in the standards-based classroom this targeted review encloses relevant scholarship in the fields of multilingual and multicultural education rooted in 4 central questions of curriculum theory: Question 1: What purposes should the curriculum serve? Question 2: How should knowledge be selected, who decides what knowledge is most worth teaching and learning, and what is the relationship between those in the classroom and the knowledge selection process? Question 3: What is the nature of students and the learning process, and how does it suggest organizing learning experiences and relationships? Question 4: How should curriculum be evaluated? How should learning be evaluated? To whom is curriculum evaluation accountable? [37] The results of the review provide educators and curriculum developers with much needed guidelines for developing comprehensive, culture and language sensitive curriculum.
\end{abstract}

Keywords: multilingual education, multicultural education, curriculum development.

Acknowledgement: the author expresses gratitude to the editors and anonymous reviewer(s) for insightful feedback of the manuscript.

\section{Introduction}

What is the relationship between language and culture? What role do language and culture play in designing curriculum that is inclusive of the needs of linguistically and culturally diverse students? What does multicultural and multilingual curriculum development look like? It is clear that the relationship between language and culture is quite close yet various disciplines and scholars take up a unique ap-

\footnotetext{
${ }^{1}$ Alsu M. Gilmetdinova, PhD, Associate Professor of Foreign Languages, Russian and Russian as a Foreign Language Department.
} 
proach to define each term and identify the bonds between them. Linguistic, social and critical sciences focus on specific elements of language and/or culture [21]. Scholarship on multicultural education acknowledges a strong interactive relationship between language, culture and learning and includes the benefits of bilingual instruction for multilingual students [10]; yet, often the assumption is that "coming to voice takes place in English only" [22]. Studies in language teaching tend to divorce language from culture, or incorporate culture only to the extent "that it reinforces and enriches, not that it puts in question, traditional boundaries of self and other" [21, p.83]. Similarly, curriculum development for multicultural education is mainly done in the English language. The purpose of this article is to integrate both culture and language into the review of curriculum development that embraces both linguistic and cultural needs of diverse students.

Multicultural education has made a number of advancements in curriculum development and theorizing. Gay [10] adopts Beauchamp's [2] conceptual model of curriculum theorizing and states the multicultural education is a mature field that meets the general criteria of curriculum theorizing. Consistency among scholars on the major principles, concepts, directions; knowledge of the historical evolution of the field; models of multicultural curriculum - they all demonstrate contributions of multicultural education to developing curriculum that provides equitable and excellent educational opportunities for students from diverse backgrounds. Sleeter's [37] work, Un-Standardizing curriculum: Multicultural teaching in the standardsbased classroom, posits that multicultural educators address four related strands of work on curriculum: "access to quality curriculum, textbook content, relevance of curriculum to students, and models of curriculum transformation" [37, p.11]. Further, Sleeter provides a framework for multicultural curriculum design that is rooted in four central questions of curriculum theory.

Question 1: What purposes should the curriculum serve?

Question 2: How should knowledge be selected, who decides what knowledge is most worth teaching and learning, and what is the relationship between those in the classroom and the knowledge selection process?

Question 3: What is the nature of students and the learning process, and how does it suggest organizing learning experiences and relationships?

Question 4: How should curriculum be evaluated? How should learning be evaluated? To whom is curriculum evaluation accountable?

The paper aims to answer these questions by reviewing relevant scholarship in the fields of multilingual and multicultural education, and focus on how both language and culture can be integrated and benefit diverse students' educational experiences. The results of the review provide educators and curriculum developers 
with much needed guidelines for developing comprehensive, culture and language sensitive curriculum.

\section{Literature review}

\section{Question 1. What purposes should the curriculum serve?}

Sleeter's [37] interpretation of this question comprises the look at curriculum as the basis for social improvement where ideals of justice and equality fuel democratic action and education serves as an opportunity to learn academic tools and knowledge from a variety of perspectives. The look at this question from multilingual lens allows expanding Sleeter's view and pondering upon objectives that multilingual curriculum can potentially have in the current world dominated by standards, accountability, and statistics [27]. The scholarship on multilingualism can further highlight political tensions, aspirations, efforts of multilingual population to be recognized and attempts to broaden the definition of social improvement to gain not only cultural but linguistic rights to achieve their academic and social success [25].

Curriculum theorists agree that nowadays the dominant trend to organize curriculum is scientific, where social and economic needs of the industry are at the center of curriculum design and implementation, with teachers cast as managers of the student achievement scores [38], where "curriculum represents a selection and organization of certain, and only certain aspects of social knowledge in the broadest sense of the term", and "whole versions of truth are at stake" [26, p. 43]. In a Hawai'ian context, for instance, this approach reveals itself as "school textbooks and curricula continue to serve the economic interest of the state by fulfilling its need for cheap labor, docile Hawaiians, and willing and able 'ambassadors of aloha" " $[19$, p. 324].

The recognition of the limitations of a curriculum that is determined by socioeconomic pressures can move beyond searching for the "who determines and controls" the curriculum. Rather, as Kliebard [20] states that "the fundamental issue, however, is not whether the list of objectives is derived from this or that method: more basic is the question of whether objectives ought to be prescribed at all" [20, p. 41]. The objectives also serve as strings to pull in the society's struggle for the means to control consciousness of people [38].

According to Bernsten and Solomon [3], "the pedagogic device, the condition for the materializing of symbolic control, is the object of a struggle for domination, for the group who appropriates the device has access to a ruler and distribution of consciousness, identity, and desire" [38, p.28]. Moreover, since curriculum historically evolved as the profession of a white upper/middle class white man, education in this sense tended to assume a dialectical relationship to reproduction. To reverse this process, deliberate attempts to "transcend the limitations of our original relations to our own prog- 
eny and to our own parents" have to made to ensure that voices of multilingual students are included in the curriculum [13, p.195].

Failure to consider the needs multilingual populations contributes to languages being endangered and lost, "because they become enmeshed in complex sociocultural and economic forces that promote the spread of larger, more powerful languages, manifested in our contemporary era as 'globalization"' [23, p.343]. Attempts should be made to create not only curriculum but 'additive policies' in place to ensure the "development of learners' competence in both the national standard language and their heritage language" [29]. The role of these political and curricula actions should go hand in hand with the organization of learning in schools, because schools and centers with native language of instruction alone cannot be "a guarantor or safeguard of intergenerational language maintenance" [9, p.250]. Holmes, Verivaki, \& Aipolo [15] also agree that they can only contribute to the process of language survival alongside other radical steps.

Outside of the educational and political realms, social factors also impact the language shift through the community. The languages slowly retreat from more social settings or domains as the community members are required to use the majority language with majority group members in those domains. ... Gradually, the rewards which result from these interactions - education, better jobs, access to government - appear to outweigh whose which emanate from community membership. [15, p.8].

To avoid this slow loss of language weight in society, multilingual curriculum design should inevitably encompass a two-way relationship between the dominant and minority language/group, and where multilingualism is viewed as a norm for all, not an exception [7]. Unfortunately though, in many societies, including those in Latin America, bilingual intercultural education is still conceived "in terms of handful proposals in favor of Indians. It is not yet considered an invigorating political proposal for the whole Bolivian, Mexican, Ecuadorian or other Latin-American nation" [33, p.461]. To secure a genuine interest, cultural and linguistic exchange conscious actions ought to be taken by different cultural actors; local indigenous or other minority languages, ethno-educational processes and other cultural elements need to be incorporated into the curriculum [33].

Multicultural and multilingual portions of the curriculum could be built upon "the mother tongue in its own right as a language of education and of cultural expression and transmission [23, p. 338-339], include traditional stories that imbue feelings of cultural pride and identity in students [42], and materials that are not only accessible through the conventional literacy forms, reading and writing, but also through-the-air to meet the needs of deaf children [24]. 
Fairly successful examples of developing multilingual curriculum can be found in Ecuador, where the country has systematically rebuilt the curriculum using Ecuadorian Intercultural Bilingual Education Model (MOSEIB) [32]. Over the course of the 20th century the country sought to diversify the practices seeking to construct educational curricula for each of the 28th peoples forming the 13 different nationalities [33]. The struggles for equality have not gone smoothly, as the forces to spread Hispanic catholic values, promote assimilation to construct a nation state, and military actions forbidding the use of Kichwas for the instruction of children were under way. However, with "active participation of parents, community and educational leaders, teachers and national and international organizations in the educational process (Oviedo, 2004)", the MOSEIB continues to be used in Ecuador [33, p. 458].

The struggles for cultural and linguistic rights in the UK have not been as successful as those in Ecuador so far, as the "National Curriculum provision is far from offering 'quality', in terms of any additive definition of 'equal opportunity', to our bilingual pupils" [27]. So, the opportunities for social improvement, equal chances for just education are much to be desired in many countries of the world, where children of "different class, ethnic and racial background have the same advantageous circumstances of success in selection and examination" [34, p.11-12].

Citing Barack Obama's speech in 2008 on the importance of multilingualism in the American school system, Hornberger and Link [18] so aptly described the need to consider multilingual population in the current curricula changes and to finally "reconcile the schizophrenia of US educational policy that for most of the nations' history has sought with one hand to enhance English speakers' foreign language capacity while with the other to eradicate ELL's language expertise, often in those very same languages" [18, p.274]. Hopefully, the changes will not take long to appear.

Question 2. How should knowledge be selected, who decides what knowledge is most worth teaching and learning, and what is the relationship between those in the classroom and the knowledge selection process?

"What matters in the construction of multilingual curriculum?" would be the reworded question based on the Grumet and Stone's [13] statement: "those of us in curriculum studies care about what matters to other people, for the construction of curriculum is always a decision about what matters [13, p.183]. What matters to a variety of linguistically and culturally diverse populations would differ, but the awareness of the absence of a single interpretation of 'what knowledge is of most worth' and 'how schools should go about teaching it' is important. Watkins [41], for example, describes black curriculum orientations that continue to fight against the oppressiveness and separateness of U.S. society and "to develop as both a part of and separate from the larger curriculum movement [14, p. 336]". What indige- 
nous peoples place as the core curriculum can also differ: "our goal was to create a text that preserved the narrative flow of the original transcribed/translated stories, keeping as much of the translated text as possible, while, at the same time, making it accessible to children" [42, p.125]. In Arapaho communities, the idea of performing a story is essential in knowledge transmission and acquisition, and it fits the purpose of creating bilingual texts produced by most learned and traditional elders: small-scale text production, of an ephemeral nature, in a context where sharing social knowledge provides access to intimate information about the producers of the texts and the contexts of their production, would seem to allow for an interesting hybrid form of performance, drawing on oral traditions, but enacted in literacy. [4]

"If preservation of stories seems crucial to maintaining the language used in the stories" is virtually universally common among indigenous groups, more rigorous process is implemented to select, encode and impart knowledge in native language to next generations of Yup'ik communities in Alaska [42, p.120]. Careful recording, transcription, translation of the stories is essential to capture the cadence of the spoken language, voice, inflections, pitch tone, singing elements, mnemonic cues. The illustrations are also considered of great value as "picture storybooks from traditional oral stories can further enhance children's school-based literacy and reading comprehension" [42, p.122].

Overall, the characteristics of a culturally and linguistically based curriculum may have the following components: hands-on activities, multiple intelligences, culturally-relevant pedagogy, subsistence activities and survival skills, cultural activities, developed by the community leaders and bilingual teachers, and other curriculum development resources [42,23].

For the ingredients of multilingual curriculum to work well, the process of content design and use should reflect a meaningful communication of all the stakeholders, policy makers, researchers, school administrators, teachers, parents, community [13]. New channels connecting these groups of people, new means of communication must be worked through as "action requires community, for the dyads of home and school, private and public, reproduction and production, self and language, and intentionality and reflexivity cannot be mediated only intellectually" [13, p.196]. In terms of addressing the needs of deaf students for whom ASL is the native language and written English is second, specialists acknowledge the responsibility of teachers and families to learn ASL while deaf child learn both ASL and written English [24].

Lastly, the knowledge worth teaching multilingual students can include Hornberger's [16] theory, continua of biliteracy, which offers " lens that enables both government and classroom policy-makers [28] to envision and incorporate students' mo- 
bile, multilingual language and literacy repertoires as resources for learning" [18, p.274]. The description of the learning process using this framework will be discussed in the next section of the paper, but what is important to reiterate is that knowledge selection process and relationships among the stakeholders are crucial to avoid situations when multilingual students are ignored or only superficially included.

As the scholarship on multicultural curricula increases, so does the criticism of its overt and hidden ideologies which often promotes values and knowledge of the dominant society and aims to produce citizens who fulfill their roles in the scientific curricula of the capitalistic machine. Anyon's [1] depiction of several school discourses illustrates how hidden curriculum of schoolwork tacitly prepares students to develop certain social identities and relate to the process of production in a particular way. In her analysis of working class, middle class, affluent professional and executive elite schools she discovered that in these educational settings differing curricular, pedagogical, and pupil evaluation practices emphasized different cognitive and behavioral skills in each social setting and thus contribute to the development in the children of certain potential relationships to physical and symbolic capital, to authority, and to the process of work. [1, p.10]

Hawaiian curriculum in Kaomea's [19] critique also reveals the workings of the hidden curriculum that projects on the native population tourist-catering mentality, which she argues has not something inherently Hawaiian, "but instead is something that has been taught to us over and over again, beginning with a first lesson from Captain James Cook" [19, p.337].

Hidden curriculum cannot only be manifested in the content of the textbooks alone [19], but be built into the standards as well. Sleeter and Stillman [38] conducted a content analysis of several California frameworks and standards and found that "states curriculum standards fit within a political movement to reconfigure power relations among racial, ethnic, language and social class groupings" [38, p.27]. More specifically, their structure, word choice, tacit cues and references make it very hard for teachers to implement linguistically and culturally responsive pedagogy [40]. Sleeter and Stillman [38] assert that the documents ignore first language literacies and language proficiencies of students who speak languages other than English; the internal logic of these standards varies so much that it makes it difficult to construct interdisciplinary connections. More so, even though California's reading/language arts standards encourage balanced instruction, multilingual students' needs are overlooked, as this type of teaching fits more "for students who read English as or above grade level" [38, p.36]. The content of history/social science framework also projects dominant perspectives on the past events, for instance "it casts colonialism not as the taking of land, life and sovereignty, but rather as the spread of reason, ideas, and liberty" [38, p.38]. In cases where revisions to the cur- 
riculum and standards are made, they tend to take the form of "cosmetic adds-on overlaid on top of the original" [19, p.331].

As the selection of worthy knowledge depends on the "eye of the beholder", the eye should not miss the novel features of new 'problems' or dismiss them as 'impractical' [35; 36]. The construction of meaningful discourses should be based upon deliberation in "which knowledge, power and desire are mutually implicated in each other's formations and deployment" [35; 8, p.316]. The very foundation of the conventional literacy in society should be challenged to accept other forms and manifestations of knowledge. Cowell [4] suggests that enforcing indigenous populations to comply with conventional forms of literacy can be detrimental to the oral-based cultures and the problem stems not from the literacy per se, but in the "function of the specific forms that literate texts and knowledge take in large-scale, capitalist society" [4].

The implications for the selection of knowledge, relationships among stakeholders and the ideology of decision-makers can and should be questioned to address the needs of multilingual students. By recognizing the problematic areas, dualism that shapes our reproductive and educational experiences, it is possible to offer curriculum that creates all children new possibilities that extend the definitions of literacy [13]; includes English language development standards for English language learners [5]; offers a two-way learning experience for students from different linguistic and cultural backgrounds, for instance, by including traditional oral storytelling into "school-based literature curriculum that reflects state academic standards" [42, p.120]. Such curricula should unpack the links between the economic needs of society and curriculum that reproduce the status quo and thwart social improvement for certain groups of people [19], and it should position itself as element of a larger system, where preparation of curricula goes side by side with changes in teacher education, professional development, and attitude towards language minority students; additive policies [29], and learning and sharing one another's languages and cultures [14].

Question 3. What is the nature of students and the learning process, and how does it suggest organizing learning experiences and relationships?

All over the world, countries witness increases in immigrant populations, especially in the USA, Russia, Germany, the UK, France, Canada. Using the case of the USA, one can see the growing statistics: 'one in five students in the United States is the child of an immigrant' [qtd. in 18, p.262; 39], "from 1993 to 2003, the growth of English language learners in elementary and secondary schools was $84 \%$ in relation to the $14 \%$ rise by the general student population" [12, p.2]. However, these changing demographics in schools across the U.S. and in many other coun- 
tries, large body of scholarship on benefits of multilingualism do not render substantial changes in national curricula [18]. Ideally, curricula should incorporate the needs of students who speak languages other than English at home by making use of learning theories that consider these students' repertoires as "complexes of linguistic, communicative, semiotic 'resources people actually possess and deploy', namely 'concrete accents, language varieties, registers, genres, modalities of writing"' [18, p.267]. In particular, one of the theories, continua of biliteracy, suggests that bilingual students' learning occurs along the range of continua, where communication takes place in two or more languages in or around writing [16]. This notion of continua, according to Hornberger blurs the boundaries between what traditionally is characterized in terms of polar opposites, such as first versus second languages (L1 vs L2), monolingual versus bilingual individuals, or oral versus literate societies, it has been increasingly clear that in each case those opposites represent only theoretical endpoints on what is in reality a continuum of features.

The development of biliteracy and bilingualism happens along the nine different continua (macro-micro, oral-literate, bilingual monolingual; productionreception, oral-written, L1-L2; successive-simultaneous exposure, convergentdivergent script, similar-dissimilar structure) represented in three figures - the continua of biliterate contexts, the continua of biliterate development in the individual, the continua of biliterate media. Multilingual students' learning develops in 'the dynamic, rapidly changing and sometimes contested spaces along and across multiple and intersecting continua" and curriculum should reflect that [17, p.264].

The linguistically diverse student body does not only bring different languages to the classroom, but also different experiences, knowledge, and skills that should be tapped into the learning process. Considering community and student characteristics, resources, indigenous or otherwise culturally different teaching styles is essential for second language learners as they try to build their academic skills on everyday life experiences and family-based knowledge [23, 38]. Moreover, Hornberger and Link [18] argue that "refusing to acknowledge the language resources of students and their families limits the possibilities for students' educational success and achievement and shuts down opportunities for the development of multilingualism" [18, p.262]. Deaf Bilingual-Bicultural (DBi-Bi) Education and Whole Language advocates share essentially the same goal as second language scholars: "to encourage connections between school curriculum and real life experiences and values" [24, p.293]. Consequently, it is imperative to build a bridge from where students are when they come to school to curriculum that connects their linguistic and cultural resources, skills and concepts, supports maintenance and growth of individual languages and facilitates access to mainstream power and influence [26]. 
The diverse nature of students also calls for adapting to new learning processes that are most effective for multilingual students. In a recent publication, Hornberger and Link [18], argue for the use of translanguaging and transnational literacies. They define the former as "a purposeful pedagogical alternation of languages in spoken and written, receptive and productive modes" and the latter as "literacy practices that draw on funds of knowledge, identities, and social relations rooted and extending across national borders [18, p.272]. The inclusion of these practices in the conceptualization of curriculum can result in the use "bilingual label quests, repetitions and translation across languages" in the classroom [18, p.272]. It can stimulate students to establish "identity positions both oppositional to and encompassing of institutional values" and allow teachers to endorse "simultaneous literacies and languages to keep pedagogical tasks moving" [18, p.272]. Furthermore, instructional practices themselves would undergo changes that prompt contextualized rather than skill-driven instruction, and urge teachers and students to make "connections between language, thinking, values, culture, and identity" [38, p.30]. DBi-Bi Education will follow similar modifications, and involve "the incorporation of native sign language and the written majority language as the principal languages of communication and instruction" [24, p.294].

The nature of multilingual students, their learning characteristics and needs logically lead to the discussion on ways to effectively organize the learning experiences of the students. Design and implementation of multilingual curriculum within the United States and other countries suggest several features common across the languages and contexts: use of vernacular languages, locally developed curriculum, relatively consistent funding over the years, continuity of leadership, prolonged and productive collaboration with experts within and outside the community, home literacy in native languages, positive attitudes towards language, national bilingual intercultural education development plan (state policie), professional training [23; $26 ; 15 ; 33]$. Among other components that can enhance curriculum and instruction to provide full equality for multilingual students with respect to language, scholars mention the following: community support and participation from the beginning, residential continuity, resistance to inter-ethnic marriage, community identified religious organizations, promotion of indigenous languages at the national and international level, view of language as key to learning and multilingualism as a resource, adequate assessment, presence of national organization, dual language materials, opportunity to study mother tongue at the level of examinations, ESL/bilingual teachers, established written form of language, 'knowledge about language' curriculum strand $[5 ; 15 ; 29]$.

Organizing effective learning in and out of classroom for deaf students requires dispelling the myths about DBi-Bi Education. According to Mason \& Ewoldt [24], 
there is still lack of apprehension that ASL is indeed a language and the native language of deaf students; that systematic use of sign language at home and in school will enhance students' chances of achieving academically and linguistically; that proficiency in sign language facilitates learning of oral languages; and that ASL like structures in deaf students' writing are due to learning written English as a second language, and not to an intrusion of ASL. The scholars also conclude that within the Whole Language philosophy framework, scholarship on second language acquisition can be adapted and used in many ASL contexts.

Lastly, challenging deficit perspectives about children who come from historically and socially marginalized communities and adapting learning processes and structures to what they already know imply modifying the relationships among social agents. Curriculum that is sensitive to the peculiarities of linguistically diverse students' needs to go beyond the inclusion of arguments against ignorance and racism and embrace interculturality as one of its fundamental principles [33]. More so, commitment to work against racism can be further developed by analyzing the identities of multilingual and multicultural students which are not monolithic.

Realizing that there are partial narratives that some social groups or cultures have and other can never know, but that are necessary to human survival, is a condition to embrace and use as an opportunity to build a kind of social and educational interdependency that recognizes differences as 'different strengths' and as 'forces for change'. [8, p.319]

Understanding of the multiplicity of identities of multilingual students and the value of dialogs should not go unnoticed. Recognition of Deaf and hearing cultures should be based on mutual respect and tolerance [24]. Most importantly, the spaces for "fluid, multilingual, oral and contextualized practices and voices" at all levels should exist and be provided in the curriculum [18].

All in all, multilingual students require more systematic attention in curriculum and instruction in both languages in order to learn and have access to meaningful learning experience, higher education and life after school [14]. The funds of knowledge students bring to school [31], their home languages and cultures should be visible in curriculum and larger educational discourses. Particularly, they can be present in the curriculum through "humanities foundation, home school dialog, tolerance of language diversity, positive recognition and valuing of cultural and linguistic diversity" [29]. As curriculum evolves and embraces communicative, linguistic and learning needs of the students, the contexts outside of the linguistic phenomenon should also be considered, these are social, cultural, political and historical factors of where curriculum is a part in the whole [18]. 


\section{Question 4. How should curriculum be evaluated? How should learning be evaluated? To whom is curriculum evaluation accountable?}

As many multicultural movements arose from grassroots community activism [37], the leadership, awareness, ethnic and linguistic consciousness and responsibility in maintaining native languages of multilingual students should also originate from the community itself $[15 ; 23 ; 33]$. Communities whose languages are in jeopardy should adopt responsibility for the "ongoing incentive within families aimed at transmitting traditional knowledge to their children, in addition to the promotion of reading and writing skills" in the native language(s) [33, p.465]. The sources of motivation to maintain native languages most often also come from the community: "Such rewards cannot be supplied from the outside. They are to be had from within the social web of the community itself or not at all" [23, p.343]. The research by Hornberger and King [17], proves the fact that the creation of mothertongue schools "were the result of the work and aspirations of 'a small group of indigenous teachers in response to what they saw to be generally inadequate and often detrimental teaching methodologies" [qtd. in 23, p.338]. Without such leadership and increased awareness of the community leaders, erosion could be quite speedy, especially if other factors, such as the size of the group, resources, and other elements discussed in the section on effective multilingual language organization are limited.

Beyond the accountability to communities, high standards and expectations, and authentic assessments should accompany the evaluation of curriculum. First, current standards have a prescriptive nature, enforce high-stakes standardized testing and, as a result, lead to the teaching to the test and leaving little room to help ELL students and deaf children. Secondly, the standards rarely consider the special needs of multilingual students, who might not yet be fully proficient in English, and have not only language, but other cultural, social and psychological difficulties with the testing system. To complicate things even further, Sleeter and Stillman [38] conclude that "the dearth of instructional strategies for teachers of English learners and the inaccessibility of guidelines that are included discourage straying from expanding upon the curriculum, even in the interest of meeting the needs of individual students." [38, p.42]. In some states 'English only' laws make it increasingly difficult for teachers, despite their professional experience and beliefs about bilingual and biliterate development to create opportunities to help multilingual students. With the changes in ESEA [39] which seems "to foreground bilingual models over other forms of programming for those labeled 'English Learners', it remains to be seen how schools and districts across the country will work toward developing and implementing bilingual education while high-stakes testing in English remains the sole measure of students and school success" [18, p.262]. 
The scarcity of research on bilingual and alternative assessment for multilingual students is another indicator of the severe need for more systematic enhancement of curriculum, expansion of research and 'additive policy' changes [5; 12]. LaCelle-Peterson and Rivera identify four important characteristics for assessment of ELL students: comprehensiveness, flexibility, progress-orientation, student sensitivity [5]; but if this list only looks at the assessment in the English language, Heugh [14] suggests developing bilingual assessments. Her research on systematic support of multilingual classrooms in South Africa demonstrates that "bilingual assessments, in the manner of matric exams, in say, English or Afrikaans and an indigenous language... would go some way to help level the playing-field that is still heavily loaded in favor of English and Afrikaans-speakers" [14, p.102].

Alternatively, bridging the gap between equitably assessing linguistic and academic performance of multilingual students can be accomplished by means of performance and portfolio assessment $[6 ; 31]$. In other contexts, the combination of both traditional and alternative assessment can be possible to measure academic achievement of language learners [5]. In her Assessing English Language Learners: Bridges from Language Proficiency to Academic Achievement [12] carefully examines unique needs of the English language learners and describes various strategies that can guide educators to implement instructional assessment of language and content. But more research on bilingual assessment and other alternative forms of multilingual students' evaluation are in need.

In the period of demographic changes, standardization movements and urgency of the time to open up the spaces in curriculum for the multilingual students, it is important to recall the suggestion of Schwab [35] to focus not only on the top down approaches to educational changes, but to explore the classroom action and reaction, to connect theory and practice in a way that helps address the pressing questions, to implement changes in a piecemeal fashion without rushing to move to easy solutions and ultimately to always keep the current problems in the context of "what is and has been going on in American schools" [35, p. 15].

\section{Materials and methods}

Current article used Sleeter's [37] framework for multicultural curriculum design to review relevant scholarship in the fields of multilingual and multicultural education with the focus on how both language and culture can be integrated and benefit diverse students' educational experiences.

\section{Results}

The results of the review provide educators and curriculum developers with much needed guidelines for developing comprehensive, culture and language sensi- 
tive curriculum. This review was prepared in tandem with the article published in International Multilingual Research Journal "Many mansions: Conceptualizing translingual curriculum theory" [11], where the authors taking up Spivak's postcolonial discursive work argued for importance to consciously integrate and "shuttle" between the notions of translation and transcoding when building curriculum that is built on the languages, language forms and literacies, identities and ethical, political, cultural considerations of those who are being taught.

\section{Discussion and conclusion}

The review highlights a number of challenges and opportunities when designing multilingual and multicultural curriculum, which should be of high quality and relevance, integrate socio-cultural and linguistic needs of the students and build upon their knowledge repertoires. Moreover, the utmost goal should be to lay the foundation for all students, regardless of their socio-economic, linguistic, cultural, physical or other backgrounds, to become confident speakers of their native language, state language as well as myriads of other global languages. These students should be open-minded, empathetic and ready to communicate with citizens around the world. And that is only possible when educators, teachers, policymakers, administrators, parents and community members work hand-in-hand to address individual challenges that face each school district or a locale. The literature review provided a spectrum of various narratives and solutions that are developed in a variety of regions around the world to support immigrant populations, native peoples or other disadvantaged groups. Russia is not an exception. With over 100 nationalities, schools located in impoverished regions, children with special needs (for instance, deaf children), Russian educators should stay abreast of global scholarship initiatives to question similar inequalities that pervade our education system. For instance, there are high stakes standardized high school graduation exams that have a very prescriptive nature and enforce specific standards and content of curriculum (Единый государственный экзамен), or one can see restrictive policies that limit the rights of multilingual citizens to study in their native language, if it is not state language, Russian. All in all, those who dedicate themselves to building a just, modern and forward-looking generation of citizens are to keep in mind that the purpose of curriculum, its content, learning nature and evaluation are ingrained in intertwined webs of language and culture. 


\section{BIBLIOGRAPHY}

1. Anyon J. Social class and the hidden curriculum of work. Journal of Education. 1980. No. 162 (1). Pp. 67-92.

2. Beauchamp E.R. Reform traditions in the United States and Japan. Educational Policies in Crisis. 1986. No. 3-22.

3. Bernstein B., Solomon J. 'Pedagogy, identity and the construction of a theory of symbolic control': Basil Bernstein questioned by Joseph Solomon. British journal of sociology of education. 1999. No. 20 (2). Pp. 265-279.

4. Cowell $A$. Bilingual curriculum among the Northern Arapaho: oral tradition, literacy, and performance. The American Indian Quarterly. 2002. No. 26 (1). Pp. 24-43.

5. Cummins $J$. Dilemmas of inclusion: Integrating English language learners in standards-based reform. In J. Cummins (Ed.) Language, power, and pedagogy: Bilingual children in the crossfire. 2000. Vol. 23. Channel View Books. Pp. 140-167.

6. DeFazio A. Language awareness at the international high school. Knowledge about language. 1997. No. 6. Pp. 99-107.

7. Edwards $J$. Bilingualism and multilingualism: some central concepts. In T.K. Bhatia \& W.C. Ritchie (Eds.). The handbook of bilingualism and multilingualism (2nd ed.). 2013. Pp. 5-25. Oxford, UK: John Wiley \& Sons.

8. Ellsworth E. Why doesn't this feel empowering? Working through the repressive myths of critical pedagogy. Harvard Educational Review. 1989. No. 59(3). Pp. 297-324.

9. Fishman J.A., Gertner M.H., Lowy E.G., Milan W., Fishman J.A. Ethnicity in action: The community resources of ethnic languages in the United States. The rise and fall of the ethnic revival: Perspectives on language and ethnicity. 1985. Pp. 195-282.

10. Gay G. Culturally responsive teaching (2nd ed). New York, NY: Teachers College Press, 2010.

11. Gilmetdinova A., Burdick J. Many mansions: Conceptualizing translingual curriculum. International Multilingual Research Journal. 2016. No. 10(2). Pp. 77-88.

12. Gottlieb M.H. Assessing English language learners: Bridges from language proficiency to academic achievement. Thousand Oaks, CA: Corwin Press, 2006.

13. Grumet M., Stone L. Feminism and curriculum: Getting our act together, Journal of Curriculum Studies. 2000. No. 32(2). Pp. 18-197.

14. Heugh $K$. Contesting the monolingual practices of a bilingual to multilingual policy. English Teaching: Practice and Critique. 2009. No. 8(2). Pp. 96-113.

15. Holmes J., Roberts M., Verivaki M. Language maintenance and shift in three New Zealand speech communities. Applied linguistics. 1993. No. 14(1). Pp. 1-24.

16. Hornberger N.H. (Ed.). Continua of biliteracy: An ecological framework for educational policy, research, and practice in multilingual settings. 2003. Vol. 41. Multilingual Matters.

17. Hornberger N.H., King K.A. Authenticity and unification in Quechua language planning. Language Culture and Curriculum. 1998. No. 11(3). Pp. 390-410.

18. Hornberger N.H., Link $H$. Translanguaging and transnational literacies in multilingual classrooms: A biliteracy lens. International Journal of Bilingual Education and Bilingualism. 2012. No. 15(3). Pp. 261-278. 
19. Kaomea J. A curriculum of Aloha? Colonialism and tourism in Hawai'i's elementary textbooks. Curriculum Inquiry. 2000. No. 30(3). Pp. 319-344.

20. Kliebard H.M. The rise of scientific curriculum making and its aftermath. Curriculum Theory Network. 1975. Pp. 27-38.

21. Kramsch $C$. The cultural component of language teaching. Language, culture and curriculum. 1995. No. 8(2). Pp. 83-92.

22. Macedo D., Bartolomé L.I. Multiculturalism permitted in English only. International Multilingual Research Journal. 2014. No. 8(1). Pp. 24-37.

23. Malone D.L. Developing curriculum materials for endangered language education: Lessons from the field. International Journal of Bilingual Education and Bilingualism. 2003. No. 6(5). Pp. 332-348.

24. Mason D., Ewoldt C. Whole Language and Deal Bilingual-Bicultural EducationNaturally! American annals of the deaf. 1996. No. 141. Pp. 293-298.

25. May S. Language education, pluralism and citizenship. In S. May \& N. Hornberger (Eds.), Encyclopedia of language and education: Language policy and political issues in education (2nd ed., Vol. 1, pp. 15-29). New York, NY: Springer, 2008.

26. McLaughlin D. Power and the politics of knowledge: Transformative leadership and curriculum development for minority language learners. Peabody Journal of Education. 1989. No. 66(3). Pp. 41-60.

27. Menken K. English learners left behind: Standardized testing as language policy. 2008. Vol. 65. Multilingual Matters.

28. Menken K., García O. (Eds.). Negotiating language education policies: Educators as policymakers. Routledge. 2010.

29. Mitchell R., Brumfit C. The national curriculum experience of bilingual pupils. Educational Review. 1997. No. 49(2). Pp. 159-80.

30. Moll L.C. Bilingual classroom studies and community analysis: Some recent trends. Educational researcher. 1992. No. 21(2). Pp. 20-24.

31. O'Malley J.M., Pierce L.V. Authentic Assessment For English Language Learners: Practical Approaches For Teachers Author: J. Michael O'Malley, Lorrain. 1996.

32. Oviedo A. Development and counter development, in rural basic education in Ecuador. Unpublished paper. CADES, Katholieke Universiteit, Leuven, Belgium. 2004.

33. Oviedo A., Wildemeersch $D$. Intercultural education and curricular diversification: the case of the Ecuadorian Intercultural Bilingual Education Model (MOSEIB). Compare. 2008. No. 38(4). Pp. 455-470.

34. Rex $J$. Equality of opportunity, multiliculturalism, anti-racism and 'Education for All'. In G. Verma (Ed.) Education for All: A Landmark in pluralism. Lewes: Falmer, 1989.

35. Schwab J.J. The practical: A language for curriculum. The school review. 1969. No. 78(1). Pp. 1-23.

36. Schwab J. The practical: A language for curriculum. In D.J. Flinders \& S.J. Thornton, Eds., The curriculum studies reader. Pp. 103-118. New York: RoutledgeFalmer, 2004.

37. Sleeter C.E. Un-standardizing curriculum: Multicultural teaching in the standardsbased classroom. Teachers College Press. 2005. 
38. Sleeter C., Stillman J. Standardizing knowledge in a multicultural society. Curriculum Inquiry. 2005. No. 35(1). Pp. 27-46.

39. United States. Dept. of Education. A blueprint for reform: The reauthorization of the elementary and secondary education act. US Department of Education, Office of Planning, Evaluation and Policy Development. 2010.

40. Villegas A.M., Lucas T. Preparing culturally responsive teachers: Rethinking the curriculum. Journal of teacher education. 2002. No. 53(1). Pp. 20-32.

41. Watkins W.H. Black curriculum orientations: A preliminary inquiry. Harvard Educational Review. 1993. No. 63(3). Pp. 321-338.

42. Webster J.P., Yanez E. Qanemcikarluni Tekitnarqelartuq [One must arrive with a story to tell]: Traditional Alaska Native Yup'ik Eskimo Stories in a Culturally Based Math Curriculum. Journal of American Indian Education. 2007. No. 46(3). Pp. 116-131.

Original article submitted 09.08.2020

Revision submitted 21.09.2020

\section{УДК 378}

\section{РАЗРАБОТКА ПОЛИЛИНГВАЛЬНОЙ И ПОЛИКУЛЬТУРНОЙ УЧЕБНОЙ ПРОГРАММЫ}

\section{А.М. Гильметдинова ${ }^{1}$}

Казанский национальный исследовательский технический университет имени

А.Н. Туполева - КАИ (КНИТУ-КАИ)

Российская Федераџия, 420111, Республика Татарстан, г. Казань,

ул. К. Маркса, 10

E-mail: Alsu.Gilmetdinova@kai.ru

\section{Аннотация}

Какова связь между языком и культурой? Какую роль язык и культура играют в разработке учебной программы, учитывающей потребности обучающихся из разных культур и говорящих на разных родных языках? Как выглядит разработка полилингвальной и поликультурной учебной программы? Научные данные по поликультурному образованию указывают на тесную интерактивную связь между языком, культурой и обучением, в основе которой лежит интеграция преимуществ двуязычного обучения для многоязычных студентов [10]. Тем не менее часто предполагается, что «озвучивание происходит только на английском языке» [22]. Точно так же разработка учебных программ для поликультурного образования в основном осуществляется на английском языке. Цель этой статьи - сделать обзор научных исследований в сфере разработки учебных программ, учитывающих лингвистические и культурные потребности обучаюшихся и взаимосвязь языков обучения с содержанием учебных планов.

${ }^{1}$ Гильметдинова Алсу Махмутовна, $\mathrm{PhD}$, доцент кафедры «Иностранные языки, русский и русский как иностранный». 
Onираясь на книгу Sleeter [37] "Un-standardizing curriculum: Multicultural teaching in the standards-based classroom”, автор делает обзор научной литературы по данной тематике, основанный на четырех центральных вопросах теории иметодики разработки учебных программ. Вопрос 1: Каким целям должна служить учебная программа? Вопрос 2: Как следует выбирать те знания, которым обучать, кто решает, какие знания наиболее чзелесообразно преподавать и изучать, и какова взаимосвязь между теми, кто находится в классе, и тем, кто создает программы обучения? Вопрос 3: Каковы особенности обучающихся и процесса обучения, как это влияет на организацию учебного прочесса и на взаимоотношения всех заинтересованных сторон? Вопрос 4: Как следует оченивать учебный план? Как следует оценивать обучение? Кому подотчетна оченка учебной программы? Результаты обзора представляют собой рекомендации преподавателям и авторам учебных программ по разработке комплексных учебных программ, учитывающих особенности культуры и языка обучаюшихся.

Ключевые слова: многоязычное образование, поликультурное образование, разработка учебных программ.

Благодарность: автор выражает благодарность редакторам и анонимным рецензентам за содержательные отзывы о рукописи.

Поступила в редакцию 09.08.2020

В окончательном варианте 21.09.2020 